\title{
浅谈增强初中历史教学的趣味性
}

\author{
刘庆福 \\ 吉林省松原市扶余市新万发镇中学 \\ DOI:10.32629/jief.v2i5.1425
}

[摘 要] 历史, 是初中阶段学生们学习的主要学科之一。在这个社会进步, 科技不断更新的时代, 社会对人才的要求变得越来越高, 教师只 有重视对学生的各方面能力的培养，才能便学生日后顺应的适应社会。在社会进步的大环境下，我国的教育事业也迎来了全新的改革方案， 新课改的提出后, 整个教学理念不再是以考试分数来衡量一个学生的学习效果，而是注重对学生核心素养的培养。因此，在初中历史教学的 过程中教师要重视教学的趣味性, 这样不但提高了学生在历史课上的注意力, 也对他们的历史核心素养的培养起到了积极的作用。以下是笔 者根据大量的调查研究后对增强初中历史教学的趣味性做出的浅谈, 为初中历史教师教学提供一些建议。

[关键词] 初中历史; 教学方法; 趣味教学

中图分类号：G434 文献标识码：A

在社会进步的大环境下，以传统教学的很多观念培养学生已无法满 足社会对培养人才的要求。因此, 教师要高度重视新课改要求, 按照新 的课程标准和教学目标来对学生进行历史教学。教师要丢弃传统教学中 以分数来评价一个学生掌握知识的能力的旧观念, 要从学生的兴趣入手, 丰富课堂内容, 扩宽他们的眼界, 提高学生的综合素质, 为学生成年后 能更好的适应社会打下良好的基础。

\section{1 增强初中历史教学趣味性的意义}

从娃娃开始, 国家就要求孩子走进课堂, 其最终目的就是成年后可 以很好的适应社会, 为民族的进步、国家的富强培养优秀人才。在目前 的大环境下, 要想成才, 就要加强对学生核心素养的培养。教师要想提 高学生的历史核心素养, 就要重视历史教学的趣味性。这样一方面可以 丰富教学内容, 使课堂教学变得更充实。另一方面, 提高学生对历史这 门学科学习的积极性, 对实现自主学习有很大的帮助。因此, 历史教学 中采用趣味性教学意义重大。

\section{2 现阶段历史教学的现状}

由于受传统教育的观念的影响, 很多学校的教师还停留在注重语文、 数学与外语这三门学科, 在观念上觉得历史这门课程是不重要的。例如, 由于不重视, 在历史教学中只用单一的讲述方式讲解书本上的内容, 既 不扩展相关历史故事也不使用多媒体教学让学生直观的去体会历史故事 场景。单一的讲述方式让学生感觉十分无聊, 也是很多学生厌烦历史学 科的主要原因。这严重影响了学生的发展。

\section{3 提高历史教学趣味性的方法}

3.1 利用多媒体进行教学

目前, 利用多媒体的地方随处可见, 学校也不例外, 多媒体早已是 每个班级必备的教学设备之一。在初中历史的教学的过程中, 为了增加 历史教学的趣味性, 教师可以将多媒体教学方式引入到历史课堂中来, 这样的教学方式不但可以丰富历史教学内容, 也可以让学生通过多媒体 展示的视频直观的看到一些关于历史课本中讲述的历史内容。这样的教 学方式使学生的注意力提高了, 也可以更好的将学习内容更好的得到延 伸。例如, 在初中历史课上学习《虎门销烟》这部分内容时, 教师可以 给学生播放林则徐在广州虎门集中销毁鸦片的视频片段, 这样可以加深 学生对历史内容的记忆, 同时也吸引学生的兴趣, 促进学生的爱国情怀。

3.2 多种教学模式

由于历史内容与我们的生活差距很大, 尤其是对于初中生年龄尚小, 思维和理解上还都不够完善, 这使得学生对历史背景的很难真正的体会, 对学生学习历史带来很大的困难。为了克服这个障碍, 就需要教师备课 时多加注意, 尽可能多的采取不同的教学方式引导学生学习历史知识。
例如, 在教学过程中教师可以采用多角度提问的方式引导学生去理解所 讲解的历史内容。提问后, 教师不要忙于公布答案, 要让学生尽可能的 去思考, 也可以采用小组讨论的方式让学生们互动起来。分组讨论后, 让每一个小组学生都选出一个代表来发言, 由于每个人的想法不同, 因 此给出的答案也不尽相同。教师要在听完每个小组的答案后, 不管对错 都要以鼓励的方式来应对。这样既尊重了学生, 也提高了他们的历史学 习积极性, 对他们学好历史这门课程有很好的促进作用。

3.3 加入时事政治, 扩大学生的知识范围

人们之所以要学习历史, 不仅仅是扩大自己的知识范围, 而是很多 时候人们可以借鉴古人的智慧和教训, 来使我们少走弯路。为了更好的 扩大学生的知识范围, 学会更好的借鉴, 初中历史老师应该多关注当前 的时事新闻, 将一些相关的时事新闻与所学的历史内容结合起来, 让学 生去思考、讨论, 让学生加深历史学习内容记忆的同时感受到学习历史 的意义, 是学生真正的喜欢上历史这门学科。

3.4 开展相关的历史活动课, 增加学习趣味性

教师在历史教学过程中, 开展相关的历史活动课, 也是增加历史教 学趣味性的一种好的方法。在历史教学内容中, 每个历史故事都离不开 人类的参与。教师可以让学生们在所学的历史内容中, 把自己喜爱的人 物找出来, 上台前来演一演。教师可以分小组, 或者让学生自行结组的 方式进行多人表演, 也可以让学生根据自己的理解来丰富当时的故事情 节。为了帮助学生们更好的完成表演, 提高学生的兴趣, 教师可以根据 学生所选择扮演的人物在网上、或者实体店里帮助学生去租借相关的服 装、道具。这样既可以更好的还原历史场景, 又可以提高学生参与其中 的积极性, 让学生在快乐中学习历史知识。

\section{4 结束语}

总而言之, 在社会进步的大环境下, 社会对人才的要求越来越高, 以传统教学的很多观念培养学生已无法满足社会对培养人才的要求。因 此初中教师要重视对学生历史核心素养的培养。在初中历史教学过程中, 重视增加历史教学的趣味性, 这样不但提高了学生在历史课上的注意力, 也可以很好的提高学生的历史核心素养的培养, 对学生今后的成长、成 才具有重大的意义。

\section{[参考文献]}

[1]杨茂同.初中历史创新教学策略浅谈[J].新课程,2020(37):152.

[2]杨国民.初中历史教育教学中高效课堂的构建路径研究 [J].新课 程,2020(37):173.

[3]陈岩.基于学科素养探索如何在信息化条件下拓展初中历史课堂 教学[J].新课程,2020(37):5. 